\title{
Evaluation of requests at the hotline established by TRNC Higher Education and foreign relations Office in Covid 19 pandemic process
}

\author{
Evaluación de solicitudes en la línea directa establecida por la Oficina de \\ Relaciones exteriores y educación superior de TRNC en el proceso da \\ pandemia do Covid 19
}

\section{Avaliação das solicitações da linha direta estabelecida pelo TRNC Higher Education and Foreign Relations Office no processo da Pandemia do Covid 19}

\author{
Seçil Besim Ayhan ${ }^{1}$ (D) , Şengül Başarı ${ }^{1}$ (i) Ziya Öztürkler $^{2}$ (D) Senem İnce ${ }^{2}$ (D)
}

\author{
${ }^{1}$ Near East University, Cyprus, Turkey. \\ ${ }^{2}$ TRNC MEKB YODID, Cyprus, Turkey. \\ Corresponding author: \\ Author's full name: Seçil Besim Ayhan \\ Email: secil.besim@neu.edu.tr
}

How to cite: Ayhan, S. B., Başarı, S., \& Ince, S. (2021). Evaluation of requests at the hotline established by TRNC Higher Education and foreign relations Office in Covid 19 pandemic process. Revista Tempos e Espaços em Educação, 14(33), e15731. http://dx.doi.org/10.20952/revtee.v14i33.15731

\begin{abstract}
In accordance with the new social order required by the new type corona virus, several areas such as education, health, culture and transportation continue to transform with the social policies followed by states. The states, where the virus has spread and affected the whole world, make new regulations in the context of social policy and develop new models. In this case, it is seen that a link is established between politics and biological life. Depending on biological processes, governments focus on the needs of the era and social life. Thus, it is observed that a "bio-political" transformation is under construction. After the Covid 19 pandemic, all governments have imposed new social regulations so that they can implement education policies as an effective social government policy. In this regard, the statements that it would be the right decision to interrupt face-to-face education for a while in educational institutions came to the fore. In addition, the necessity of taking social measures in order not to keep students away from education and to ensure the continuity of education was also among the issues emphasized. From this point of view, the aim of the study is to evaluate and interpret the requests submitted by university students studying in our country during the Covid 19 pandemic to the hotline established by the TRNC Higher Education and Foreign Relations Office (YÖDID). The study was carried out with a qualitative method and uses a case study
\end{abstract}


design. Hotline reports were used as data collection tools. Findings obtained were interpreted by descriptive analysis. Requests between 07 April - 17 May 2020 have been included in the research. Support requests focused on issues such as return to the country, food, online education problems, payment problems and scholarship.

Keywords: Pandemic Process. Social Life. Education System. Higher Education.

\section{RESUMO}

De acordo com a nova ordem social exigida pelo novo tipo de vírus corona, diversas áreas como educação, saúde, cultura e transporte continuam se transformando com as políticas sociais dos estados. Os estados, onde o vírus se espalhou e afetou todo o mundo, fazem novas regulamentações no âmbito da política social e desenvolvem novos modelos. Nesse caso, verificase que se estabelece um vínculo entre a política e a vida biológica. Dependendo dos processos biológicos, os governos se concentram nas necessidades da época e da vida social. Assim, observase que uma transformação "biopolítica" está em construção. Após a pandemia de Covid 19, todos os governos impuseram novos regulamentos sociais para que pudessem implementar políticas educacionais como uma política governamental social eficaz. Nesse sentido, vieram à tona as afirmações de que seria uma decisão acertada interromper por algum tempo o ensino presencial nas instituições de ensino. Além disso, a necessidade de tomar medidas sociais para não afastar os alunos da educação e para garantir a continuidade do ensino também foi um dos pontos enfatizados. Desse ponto de vista, o objetivo do estudo é avaliar e interpretar as solicitações apresentadas por estudantes universitários em nosso país durante a pandemia de Covid 19 à linha direta criada pelo TRNC Higher Education and Foreign Relations Office (YÖDID). O estudo foi realizado com método qualitativo e utiliza o desenho de estudo de caso. Os relatórios da linha direta foram usados como ferramentas de coleta de dados. Os achados obtidos foram interpretados por meio de análise descritiva. Os pedidos entre 07 de abril e 17 de maio de 2020 foram incluídos na pesquisa. Pedidos de suporte focados em temas como retorno ao país, alimentação, problemas de educação online, problemas de pagamento e bolsa de estudos.

Palavras-chave: Processo Pandêmico. Vida social. Sistema de educação. Ensino superior.

\section{RESUMEN}

De acuerdo con el nuevo orden social que exige el nuevo tipo de coronavirus, varias áreas como la educación, la salud, la cultura y el transporte continúan transformándose con las políticas sociales seguidas por los estados. Los estados, donde el virus se ha extendido y afectado a todo el mundo, hacen nuevas regulaciones en el contexto de la política social y desarrollan nuevos modelos. En este caso, se ve que se establece un vínculo entre la política y la vida biológica. Dependiendo de los procesos biológicos, los gobiernos se centran en las necesidades de la época y la vida social. Así, se observa que se está construyendo una transformación "biopolítica". Después de la pandemia de Covid 19, todos los gobiernos han impuesto nuevas regulaciones sociales para que puedan implementar políticas educativas como una política de gobierno social eficaz. En este sentido, salieron a la luz las declaraciones de que sería la decisión acertada interrumpir por un tiempo la educación presencial en las instituciones educativas. Además, la necesidad de tomar medidas sociales para no mantener a los estudiantes alejados de la educación y asegurar la continuidad de la educación también fue uno de los temas enfatizados. Desde este punto de vista, el objetivo del estudio es evaluar e interpretar las solicitudes presentadas por los estudiantes universitarios que cursan estudios en nuestro país durante la pandemia del Covid 19 a la línea directa establecida por la Oficina de Educación Superior y Relaciones Exteriores de la TRNC (YÖDiD). El estudio se realizó con un método cualitativo y utiliza un diseño de estudio de caso. Los informes de la línea directa se utilizaron como herramientas de recolección de datos. Los resultados obtenidos se interpretaron mediante análisis descriptivo. Las solicitudes entre el 7 de abril y el 17 de mayo de 2020 se han 
incluido en la investigación. Solicitudes de apoyo enfocadas en temas como regreso al país, alimentación, problemas de educación en línea, problemas de pago y becas.

Palabras clave: Proceso pandémico. Vida social. Sistema educativo. Enseñanza superior.

\section{INTRODUCTION}

Education acts as a bridge between the state and the society (Wiborg, 2000). Each state aims to convey its ideology to its society through educational policies (Sönmez, 2011). These educational policies are described as "an ideological device". These policies are determined to maintain the sovereignty of the state (Althusser, 2010). Today, the concept of educational policies includes all political principles, political decisions and political steps that aim to raise individuals with a learned social pattern in a certain educational system at the required time, to provide individuals with the desired cognitive and cultural characteristics, and to shape the society according to the education understanding accepted in the country (Eren, 2018). Considering that there is a connection between education and politics, it can be said that the education system determined according to a certain ideology is a political instrument that ensures the continuity of the society (Tural \& Karakütük, 1991).

The true determination and implementation of education policies in terms of qualifying the education system is considered an important step in the development of the state. These educational policies are in the nature of "political measures" (Charaudeau, 2002). It is seen as an effective social state policy when it can adapt to the temporal and spatial change. In this respect, the educational policies of the state are formed in line with the needs of the current age and social life. Therefore, a social state policy which is always current and valid should be employed (Eren, 2020).

Various diseases such as Bird Flu (2005), Swine Flu (2009), Ebola (2014) and Zika (2016) have been an important factor in determining the needs of social life (National Geographic-History, 2020). That is to say, these diseases have directly affected every field including social life, especially education, business world, transportation and culture. Recently, a new type of contagious disease has emerged that has the same effect in social life (World Health Organization [WHO], 2020). This new type of disease caused by a new type of coronavirus, called "Covid-19", emerged in Wuhan, the People's Republic of China and has spread rapidly all over the world as of December 2019 (Johns Hopkins University, 2020). WHO declared Covid-19 as a "pandemic" (a global epidemic) on March 11, 2020.

Considering the spreading rate of new type Coronavirus in all over the world, it has been seen that although the disease progresses like a regular flu in the infected individuals, it could lead to death among aged people (60 years of age and above) and individuals with a chronic disease or weak immune system (Chinese Disease Control and Protection Center, 2020). "Self-isolation" has been emphasized as one of the most effective methods to avoid being exposed to this new type of coronavirus, in other words, to prevent the further spread of Covid-19. Thus, it is aimed to keep individuals away from social life and let them protect themselves in their home environment (Ashour, Elkhatib, Rahman, \& Elshabrawy, 2020). Having begun to take urgent measures in line with these purposes, governments continue transformation in several fields such as education, health, culture and transportation in accordance with the new social order required by new type coronavirus using social policies. From December 2019 to today, meaning March 2020 (according to estimations till April 2021) (British Public Health Unit, 2020) governments which are affected by the global spread of the virus are preparing new regulations in terms of social policies and developing new models. In this case, it is seen that there is a link between politics and biological life. States focus on the needs of the age and social life depending on biological processes. Thus, it is observed that they are going through a "bio-political" transformation (Foucault, 2004). 
After the spread of new type coronavirus, governments imposed new social regulations so as to implement their education policies as an effective social state policy. In this regard, discourses came to the forefront arguing that interrupting education at education institutions would be a good decision. Since these institutions serve students and teachers from all social segments, interrupting education seems to have a very important role in reducing the spread of infectious diseases. However, social precautions should be taken to keep students linked with education and to ensure the continuity of education (United States Centers for Disease Control and Prevention, 2020).

As education systems are affected by this order, it is essential that education policies are implemented as an effective social policy of governments. In this context, the purpose of this study is to evaluate and interpret the requests sent to the hotline established by TRNC Higher Education and Foreign Relations Office by university students studying in our country during Covid 19 pandemic process.

\section{METHOD}

The research was carried out with a qualitative method. The design of the research was determined as a case study.

\section{Data Collection Tool}

Hotline reports were used as data collection tools.

\section{Collection of Data}

The requests between 7 April 7 and 17 May 2020 were included in the study. As these dates cover a complete lockdown, it is essential as it is the period when students feel the highest level of need while living on the island. In order to reach the data, the researchers applied to the TRNC Higher Education and Foreign Relations Office and the necessary permissions were obtained. Accordingly, hotline data were shared with the researchers.

\section{Interpretation of Data}

Findings obtained from the study were interpreted by descriptive analysis. In the descriptive analysis, descriptive examinations about the current situation of an event or phenomenon is conducted. In this study, it refers to a specific situation, the Covid-19 pandemic process and related needs. The problems experienced by higher education students regarding this case have been an important instrument in defining the situation.

\section{FINDINGS AND INTERPRETATION}

The hotline was activated on Tuesday, 7 April. Between 7 April 2020 and 17 April 2020, 923 requests were made and the requests were answered by YÖDiD. The number of requests sent between 7 April 2020 and 1 May 2020 reached 1708 and they were answered by YÖDiD. Between 1 May 2020 and 17 May 2020, 422 requests were sent and the total number reached 2130. 
Graph 1: Applications between 7 April - 17 May 2020

\section{Monthly Distribution}

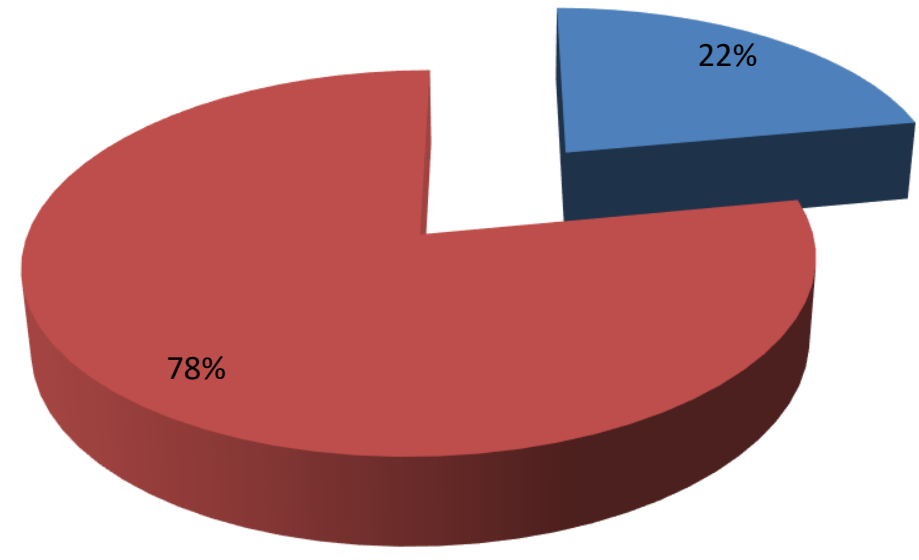

7-30 April

01-17 May

As can be seen from Figure 1, the rate of applying to the hotline was $78 \%$ in the first periods of lockdown and between 07-30 April 2020, which is the first date when the hotline was activated.

Graph 2: Distribution of Applications at Hotline by Schools



$60 \%$ of the total incoming demand came from UKÜ (International Cyprus University) - 18\% from YDÜ (Near East University) - 11\% from DAÜ (Eastern Mediterranean University) students. 
Graph 3: Distribution of Return Requests by Country in Applications Made to the Hotline

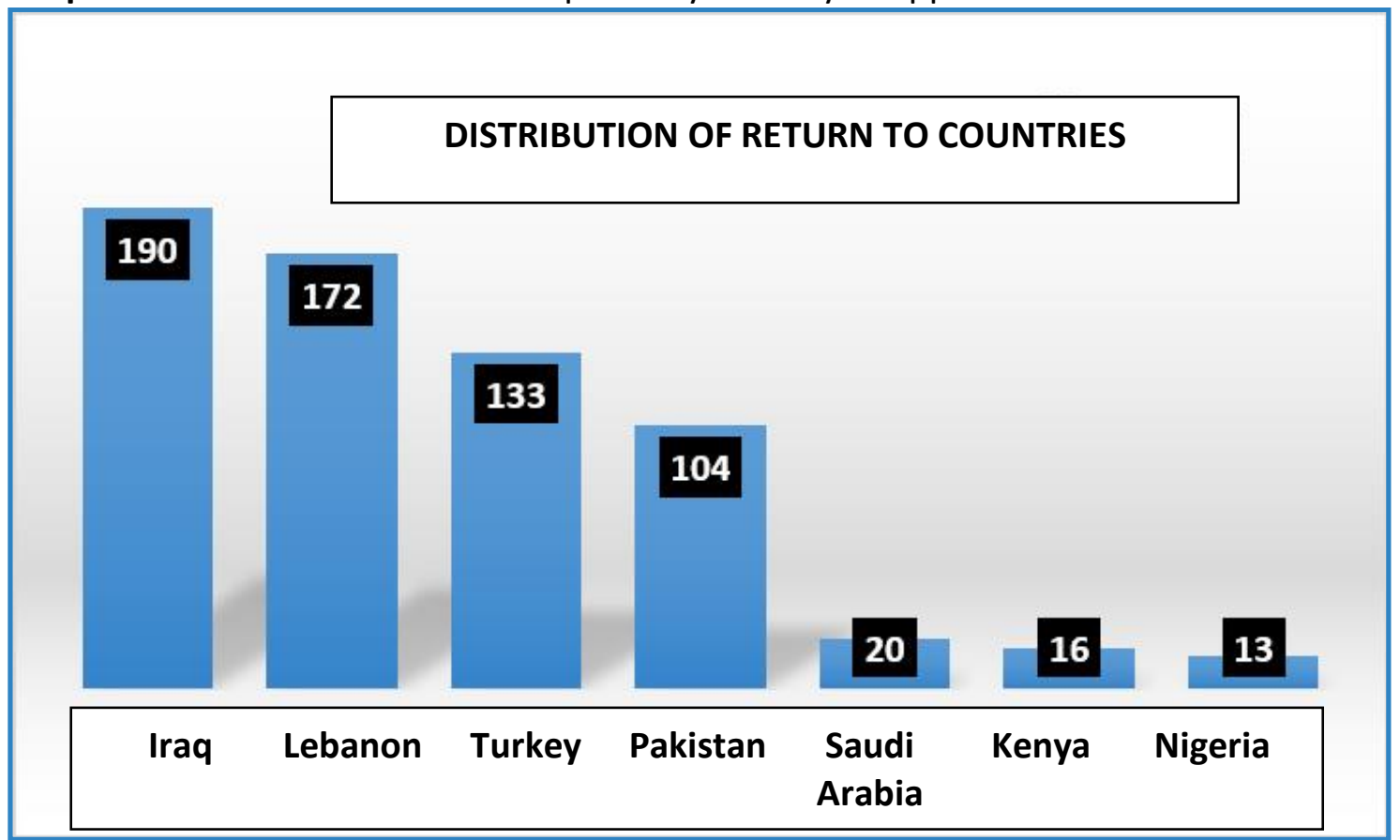

Between these dates, Iraq was the most popular country among students who applied for return to their country. Lebanon took and second place and Republic of Turkey ranked third.

Graphic 4: Distribution of Applications Made to the Hotline by Nationality

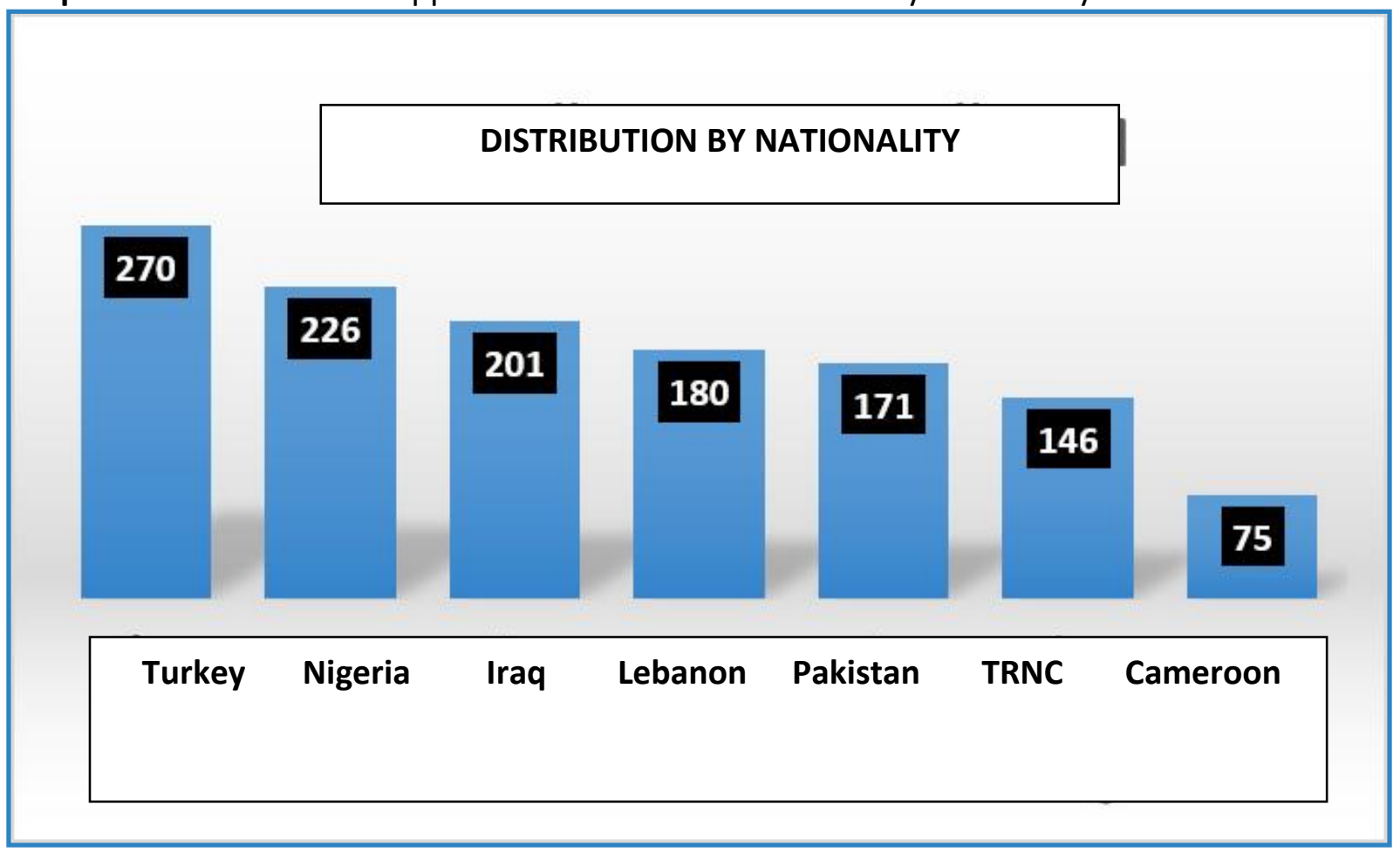

As seen in Graphic 4, students who are citizens of the Turkish Republic have applied to the hotline the most. Nigerian students rank second. 
Graph 5: Distribution of Applications Made to the Hotline by Category

\section{Category-based Distribution}

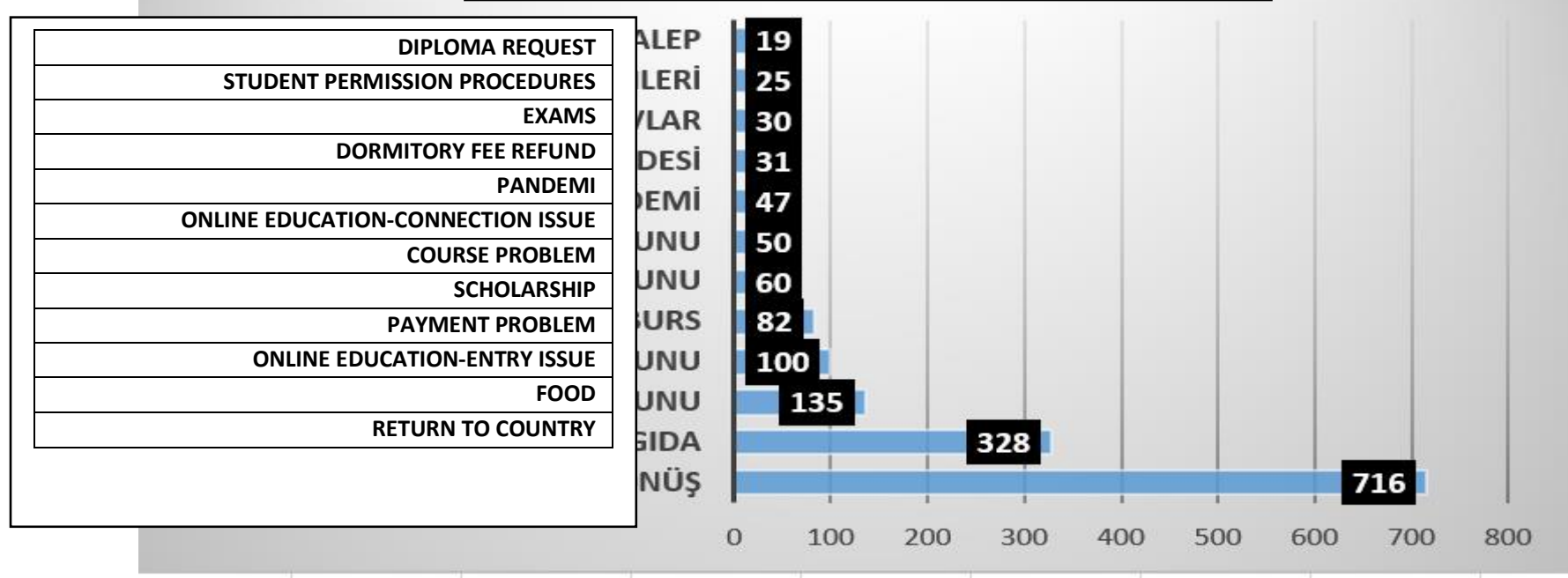

The first five orders of the incoming requests are as follows; $42 \%$ return to countries, $19 \%$ food, $11 \%$ online education problems, $6 \%$ payment problems, $5 \%$ scholarships.

Chart 6: Applications between 1 May - 17 May 2020

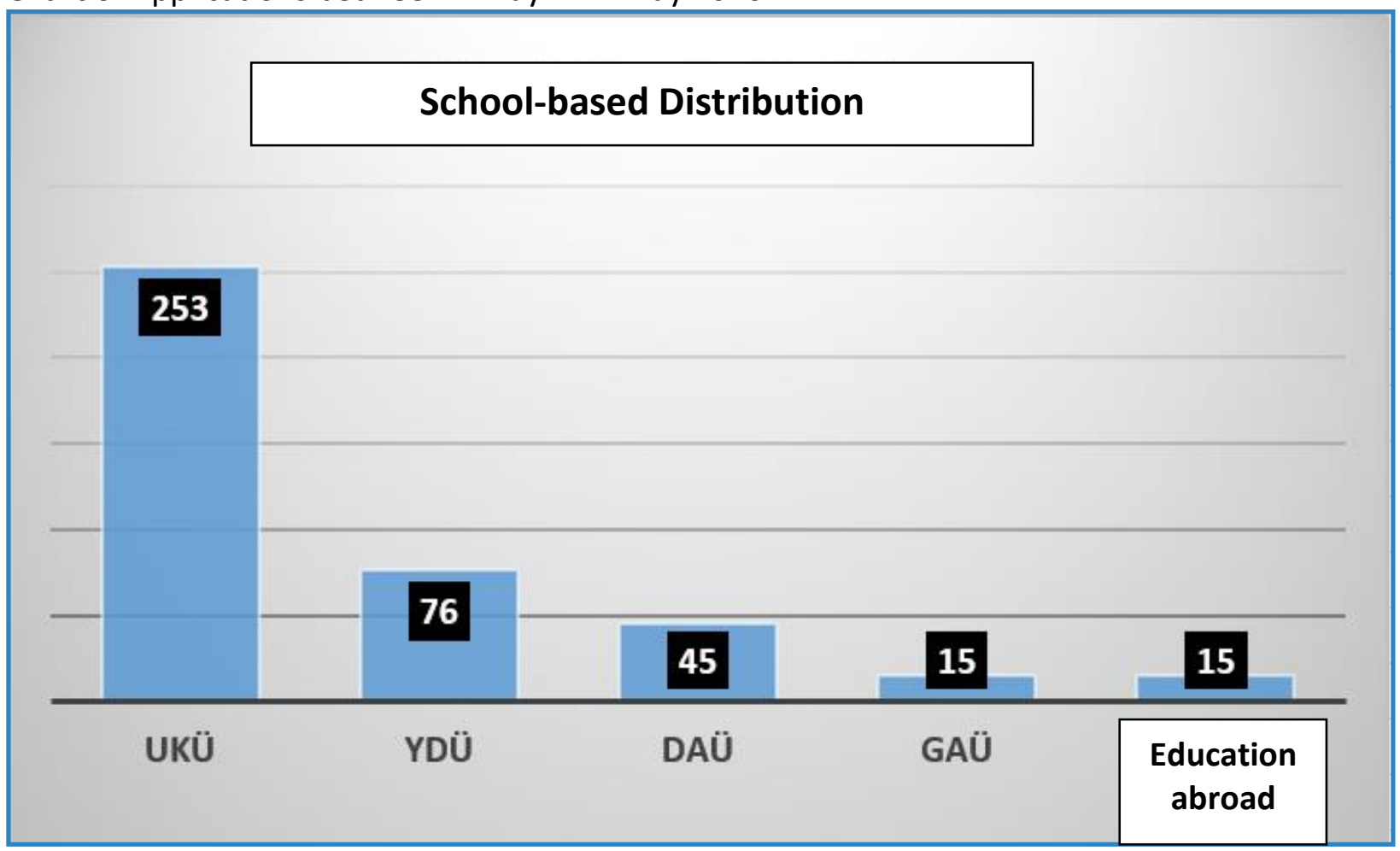
students.

Of the total requests, $60 \%$ were filed by UKÜ students, $18 \%$ by YDÜ students and $11 \%$ by DAÜ 
Graph 7: Distribution by Nationality of Applications Made to the Hotline between 1 May - 17 May 2020

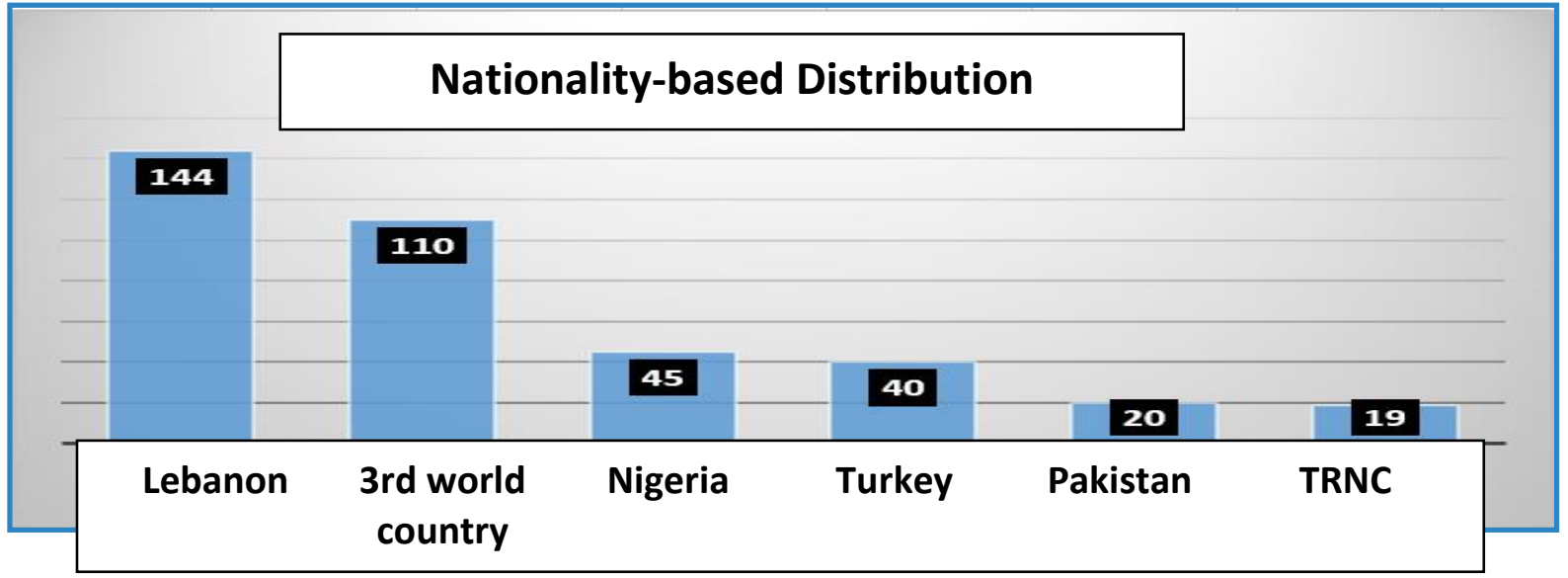

Among the students who applied to the hotline between the dates of 01-17 May 2020, the applications of Lebanese students are the most remarkable. It is observed that the number of applications of Turkish nationals who were in the first place in the first date range decreased and they fell to the fourth place in the ranking.

Graph 8: Distribution of Return Requests by Country in Applications Made to the Hotline between 01 May - 17 May 2020

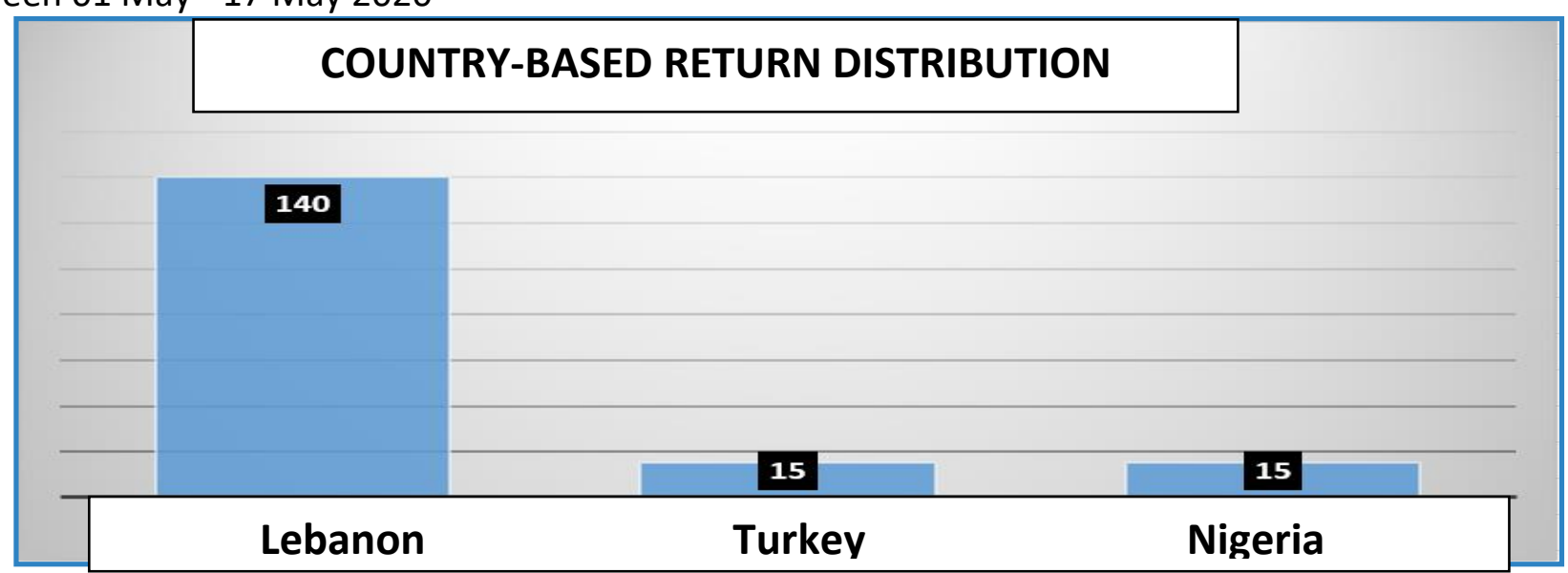

Among the students who applied to the hotline between the dates of 01-17 May 2020, the request for returning to their countries was filed mostly by Lebanese students. It is seen that Iraqi students, who ranked first in the first date range, did not file any new requests during this period. 97.2\% of Lebanese students taking the first place in the distribution based on nationality in Graph 7 applied to the hotline with a request to return to their country. 
Graph 9: Distribution of Applications Made to the Hotline between 01 May - 17 May 2020 by Categories

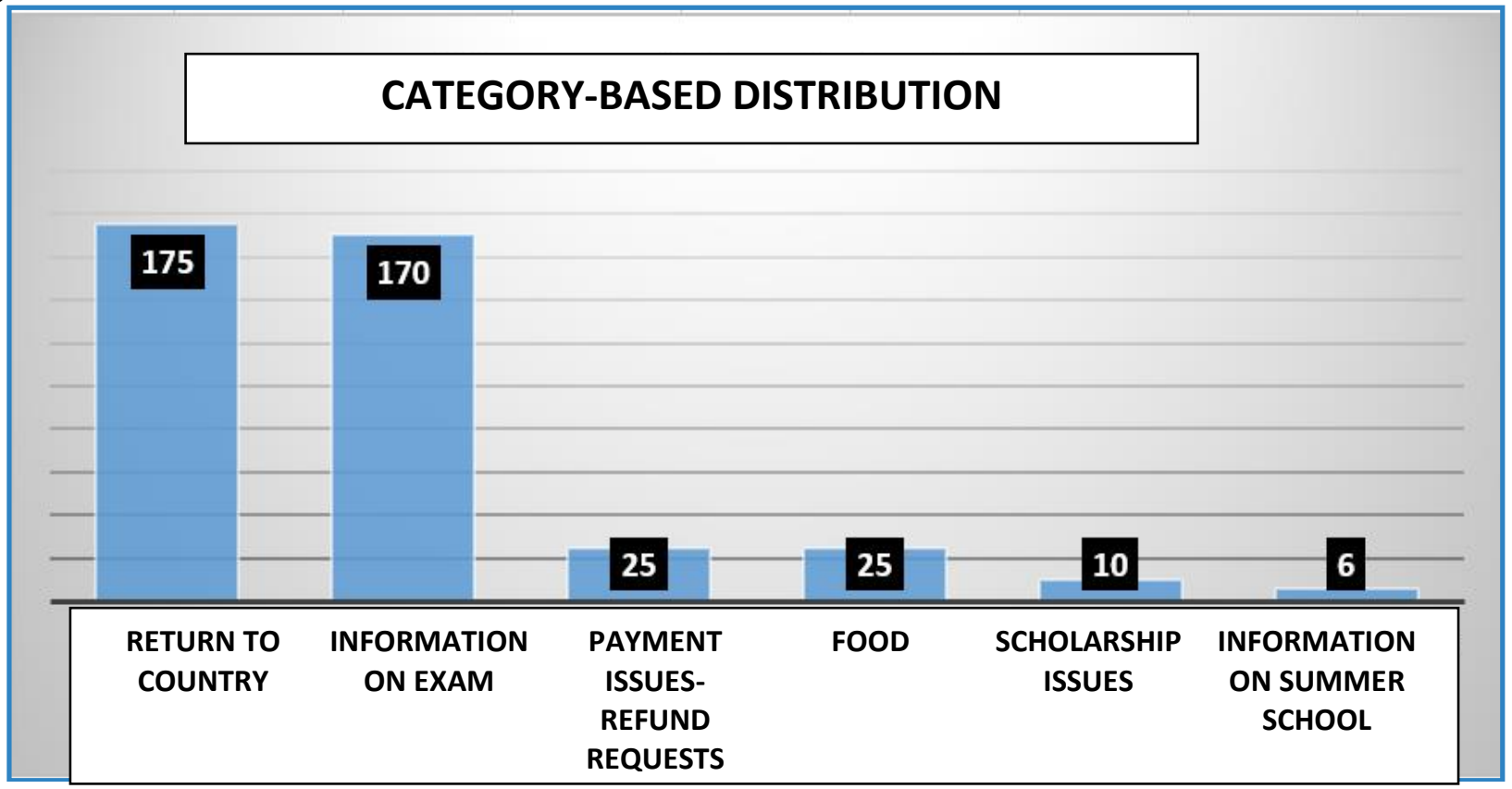

The first five orders of the requests received between 01-17 May 2020 fall in the following categories: $41 \%$ Return to Countries, $40 \%$ How the Final Exams would be held, $6 \%$ Payment problems / Fee refund requests, $6 \%$ Food, 2\% Non-payment of the scholarship.

\section{DISCUSSION AND CONCLUSION}

Support requests are concentrated on such subjects as return to country, food, online education problems, how the final exams would be held, payment problems / fee refund requests and scholarships. Kayıhan and Tönük (2011) handled education and sustainability of teaching in their research as sustainability in terms of place, and defined such issues as correct and functional usage of space. Likewise, the researchers emphasized that teaching determines the scope of a university which is sustainable in terms of research, social assistance and partnership and sustainable applications in the campus.

The part that is in line with this study is that students ask for social assistance such as food and scholarship so that they could continue their education. Yamamoto and Altun (2020), in their study on Coronavirus and Online Education, mention that education experience is evaluated by users and providers alike. They especially underline that communication for online learning is assessed as an experience on the side of receiver and giver. In addition, they argue that the perception and approaches of teaching and learning parties for distance education are different. According to studies, the prejudices and attitudes of both students and teachers affect distance education experience. They also stated that learners and teachers who are accustomed to learning face to face are not competent in using technology, and lack of infrastructure of channels offering distance education can also create inefficiency. The part compatible with this study is applying to the hotline for online education problems. In their study on the pandemic process, Demir, Günaydın and Demir (2020) stated that regulations were made regarding transportation, such as firstly reducing the vehicle capacity in domestic travels, then cancelling bus and train charters and flights, and after a while, subjecting intercity travels to permission. At this point it was declared that flights were cancelled due to the pandemic process. In this study, the applications filed by students at the hotline regarding return to their country are in parallels with this research. Karadağ and Yücel (2020) examined in their study the satisfaction of undergraduate students at universities in Turkey as 
regards distance education applications in Covid-19 process. According to the research, it was understood that only $63 \%$ of undergraduate students have internet connection at home and one third of the students do not have a computer or tablet. At the same time, it was revealed that one fourth of the students participating in the study could not continue their education due to the lack of internet or computer / tablet. In this study, it can be said that they show parallels at this point, as students expressed their problems regarding online education.

\section{RECOMMENDATIONS}

- Keeping such hotlines are active not only for the pandemic process but also in general will make students feel safe and support our island's place among the preferred countries for education.

- It is thought that the establishment of hotlines that can provide $24 / 7$ service at each university will help to solve the problems that arise faster.

- Connection problems and infrastructural deficiencies experienced in the online education process should be resolved quickly, and necessary studies should be supported in this direction.

- Regarding online education, every university should compulsorily create an in-service training program and raise the awareness of academic staff about the usage of technology.

Authors' Contributions: Seçil Besim Ayhan: conception and design, acquisition of data, analysis and interpretation of data, drafting the article, critical review of important intellectual content. Şengül Başari: conception and design, acquisition of data, analysis and interpretation of data, drafting the article, critical review of important intellectual content. Ziya Öztürkler: conception and design, acquisition of data, analysis and interpretation of data, drafting the article, critical review of important intellectual content. Senem Ince: conception and design, acquisition of data, analysis and interpretation of data, drafting the article, critical review of important intellectual content. All authors have read and approved the final version of the manuscript.

Ethics Approval: Not applicable.

Acknowledgments: Not applicable.

\section{REFERENCES}

Althusser, L. (2010). Ideology and Ideological Devices of the State (Translated by A. Tümertekin). Istanbul: İthaki Publications.

Ashour, H. M., Elkhatib, W. F., Rahman, M. M., \& Elshabrawy, H. A. (2020). Insights into the recent 2019 novel Coronavirus (SARS-CoV2) in light of past human Coronavirus outbreaks. Pathogens, 9 (3), 1-15.

British Public Health Unit (2020), Coronavirus (Covid-19). Accessed on May 11, 2020 from <https://www.gov.uk/coronavirus>.

Charaudeau, P., \& Maingueneau, D. (2002). Dictionnaire d'analyse du Discours. Paris: Le Seuil.

Chinese Disease Control and Prevention Center (2020). General questions: Covid19 prevention and control. On March 15, 2020 <http: //www.chinacdc. Retrieved from cn / en / COVID19 / 202002 / P020200219277441744175.pdf>.

Demir, M., Günaydın, Y., Demir, Ş.Ş. (2020). Evaluation of the coronavirus (Covid-19) precursors, impacts and consequences on tourism in Turkey. International Journal of Social Sciences and Education Research, 6 (1), 80-107.

Eren, E. (2018). Perception of identity as a social, cultural and political factor in nation states: National identitycentered language and education policies in the Turkish context. Turkish Studies Economics, Finance and Politics, 13

(22), 225-237. 
Eren, E. (2020). The Effect of New Type of Coronavirus on Turkish Education Policy Practices: New Regulations of the Ministry of National Education and Higher Education Council. Journal of Higher Education.

Foucault, M. (2004). The birth of biopolitics. New York: Macmillan.

Johns Hopkins University (2020). Center for System Science and Engineering. Number of confirmed cases in different countries around the world. Retrieved on April 20, 2020 from

<https://www.arcgis.com/apps/opsdashboard/index.html\#/bda7594740fd40299423467b48e9ecf6>.

Karadağ, E., \& Yücel, C. (2020). Distance Education in Universities During the New Type of Coronavirus Pandemic: An Evaluation Study within the Scope of Undergraduate Students. Yükseköğretim Dergisi / Journal of Higher Education (Turkey), 10 (2), 181-192.

Kayıhan, K. S., \& Tönük, S. (2011). Basic Education Schools As The Buildings To Build Sustainability Consciousness. Politeknik Journal, 163-171, (14), 2.

National Geographic- History (2020). Pandemics That Changed History. Retrieved on March 15, 2020 from <https://www.history.com/topics/middleages/pandemics-timeline>.

Sönmez, V. (2011). Educational Philosophy. 10th edition. Ankara: Anı Publishing.

Tural, N., \& Karakütük, K. (1991). Education Policy. Education and Science, 15, 16-24.

United States Centers for Disease Control and Prevention (2020). Interim guidance for administrators of US K-12 schools and childcare programs. Accessed on 17 March 2020 from https://www.cdc.gov/coronavirus/2019ncov/community/schools-childcare/guidance-forschools.html\#role.

Wiborg, S. (2000). Political and cultural nationalism in education. The ideas of Rousseau and Herder concerning national education. Comparative Education, Nigel Grant Festschrift, 36 (2), 235--243.

World Health Organization (2020). Location of New Type Coronavirus (Covid-19). Accessed on April 20, 2020 from $<$ https://who.sprinklr.com>.

Yamamoto, G. T. \& Altun, D. (2020). The Coronavirus and the Unavoidable Rise of Online Education. Journal of University Studies. 3 (1), 25-34.

Received: 29 March 2021 | Accepted: 20 May 2021 | Published: 28 May 2021 